\title{
Submarine landform assemblage produced beneath the Dotson-Getz palaeo-ice stream, West Antarctica
}

\author{
A. G. C. GRAHAM ${ }^{1}$, F. O. $\mathrm{NITSCHE}^{2}$, R. D. LARTER ${ }^{3}$ \& K. GOHL ${ }^{4}$ \\ ${ }^{1}$ College of Life and Environmental Sciences, University of Exeter, Rennes Drive, Exeter EX4 4RJ, UK \\ ${ }^{2}$ Lamont-Doherty Earth Observatory, Columbia University, Palisades, New York 10964, USA \\ ${ }^{3}$ British Antarctic Survey, Natural Environment Research Council, High Cross, Madingley Road, Cambridge CB3 OET, UK \\ ${ }^{4}$ Alfred Wegener Institute, Helmholtz Centre for Polar and Marine Research, Am Alten Hafen 26, D-27568 Bremerhaven, Germany \\ *Corresponding author (e-mail: a.graham@exeter.ac.uk)
}

Within Earth's ice sheets, fast-flowing ice streams are the principal components through which ice and sediment are discharged, accounting for $c$. $90 \%$ of the ice lost from the Antarctic today (Bamber et al. 2000). The processes occurring at ice-stream beds, therefore, lie at the heart of resolving how and why major icestream systems may change in the future. Although drill-cores and ice-surface seismic methods have been employed to survey the beds of some of West Antarctica's ice streams, studies are still hampered by the logistical and technological challenges associated with understanding a dynamic and spatially extensive interface buried beneath kilometre-thick continental ice (Larter et al. 2009). Here, a multibeam swath-bathymetric dataset acquired from the Dotson-Getz palaeo-ice-stream bed, offshore of West Antarctica, is described (Fig. 1a). In contrast to the modern icesheet base, the spatial coverage and quality of the marine data allow us to analyse landform evolution along an entire ice-stream bed that is both completely exposed and well preserved.

\section{Description of landforms}

The study area in the western Amundsen Sea embayment comprises three 17-39 km wide troughs that extend seaward of the Getz and Dotson ice shelves (Fig. 1a-c). These tributary troughs converge into a single well-defined cross-shelf trough that extends for $c .280 \mathrm{~km}$ away from the coastline, shoals towards the continental-shelf edge and retains a clear U-shaped cross-profile along its length (Fig. 1b). At the modern ice-shelf termini, the seafloor is typically deeper than $1000 \mathrm{~m}$ and extends to $>1500 \mathrm{~m}$ depth in places, shallowing to $c .500 \mathrm{~m}$ at the shelf edge.

The inner part of the continental shelf is floored by seismically transparent units interpreted as crystalline basement or deformed sedimentary rocks. These are overlain by sequences of prograding and aggrading stratified and locally chaotic seismic units that are interpreted as sedimentary strata of marine and glacial origin (Lowe \& Anderson 2002, 2003; Graham et al. 2009). Although age control does not yet exist for the shelf stratigraphy, it is likely that the shelf sedimentary sequence spans much of the Tertiary and Quaternary (Gohl et al. 2013), encompassing many glacialinterglacial cycles.

In front of Getz B Ice Shelf, the seafloor is predominantly bedrock and is characterized by a deep basin in which crudely streamlined lineations and a network of interconnecting channels are observed (Fig. 2a). Some channel thalwegs meander and are notably undulating, rising and falling repeatedly (Graham et al. 2009). Further along the trough streamlined lineations dominate the seafloor, many with high elongation ratios $(>30: 1)$. There is a transition to NE-trending elongate drumlins and elongate streamlined lineations $35-40 \mathrm{~km}$ north of the Getz B ice front (Fig. 1c).

Some $100 \mathrm{~km}$ eastward, in front of the Dotson Ice Shelf and within $30 \mathrm{~km}$ of the 2006 ice front (Fig. 1c), an array of elongate submarine landforms are also revealed by multibeam data, parallel to the axis of the tributary trough (Fig. 2b). These include linear grooves, small drumlinoid forms, crag-and-tails of various lengths and longer more elongate lineations, as well as non-aligned small channels which are well developed on the trough flanks and often meander inwards toward the trough axis (Fig. 2b).

A similar varied assemblage of landforms occurs in the central of the three tributary troughs, in front of Getz A Ice Shelf (Fig. 1c). Streamlined lineations with a range of elongation ratios are the clearest landform type, but larger bedrock highs mantled by, and interspersed with, drumlinoid landforms are also very common within the $c .50 \mathrm{~km}$ region seaward of the ice shelf (Fig. 1b-d). Some of these drumlinoid features have crescentic overdeepenings around their heads.

Elongate landforms converge to the north at the heads of each tributary trough, about $50 \mathrm{~km}$ from the Getz A ice front (Fig. 1c). Further large sills and bedrock highs mantled by smaller drumlinoid landforms are common across the trough floor, which is dominated by streamlined landforms of various sizes. In the $30 \mathrm{~km}$ zone north of the sills $(50-80 \mathrm{~km}$ distance along the trough; Fig. $1 \mathrm{~b}-\mathrm{d}$ ), drumlinoid landforms are most common, interspersed with flow-aligned straight to slightly meandering channels.

Immediately north of these drumlins (at $c .80 \mathrm{~km}$ along the trough), there is an abrupt transition to seafloor composed entirely of very elongate, parallel, ridge-groove lineations (Figs 1c, 2c). Seismic profiles show that this boundary coincides with a change in substrate from acoustic basement in the south to dipping sedimentary strata in the north (Fig. 1d). The lineations extend northward for tens of kilometres across this sedimentary substrate (80-150 km along the trough; Figs 1c, 2c).

With the shallowing of the trough, the lineations eventually give way to curvilinear, randomly orientated and cross-cutting scour marks (Fig. 2d). These are V-shaped in profile and occasionally have berms on either side. Along the axis of several scours, smaller corrugated-ridge sets are also visible.

The long-axis of the Dotson-Getz trough shoals continuously northward (Fig. 1d). The only break in gradient anywhere along the trough is a distinct seaward-inclined ramp near $73^{\circ} \mathrm{S}$, about $140 \mathrm{~km}$ from the ice-shelf front (Fig. 2e). The ramp is chevronshaped on multibeam data, with a point tailing off in a downflow direction. Elongate lineations superimpose the ramp and backslope, and also extend further to the north beyond the seafloor high (Fig. 2d). Still further northward, sparse multibeam-bathymetric data show that the seafloor is characterized purely by curvilinear and non-aligned scour marks that extend to the shelf edge ( $c$. $150-270 \mathrm{~km}$ along the trough; Fig. 1d).

Although relatively featureless, the continental slope at the mouth of the Dotson-Getz trough bulges seaward, consistent with the presence of a trough-mouth fan in this location.

\section{Interpretation of landforms}

The assemblage of submarine landforms comprising the DotsonGetz system can be divided into two regions of differing geology: an area of basement-floored substrate extending from the modern ice shelves for about $80 \mathrm{~km}$ to $73.5^{\circ} \mathrm{S}$; and an area floored by sedimentary strata to the north of $73.5^{\circ} \mathrm{S}$. Both regions are characterized by distinctive groups of landforms.

From: Dowdeswell, J. A., Canals, M., Jakobsson, M., Todd, B. J., Dowdeswell, E. K. \& Hogan, K. A. (eds) 2016. Atlas of Submarine Glacial Landforms: Modern, Quaternary and Ancient. Geological Society, London, Memoirs, 46, 345-348, http://doi.org/10.1144/M46.176 (C) 2016 The Author(s). Published by The Geological Society of London. All rights reserved. For permissions: http://www.geolsoc.org.uk/permissions. Publishing disclaimer: www.geolsoc.org.uk/pub_ethics 

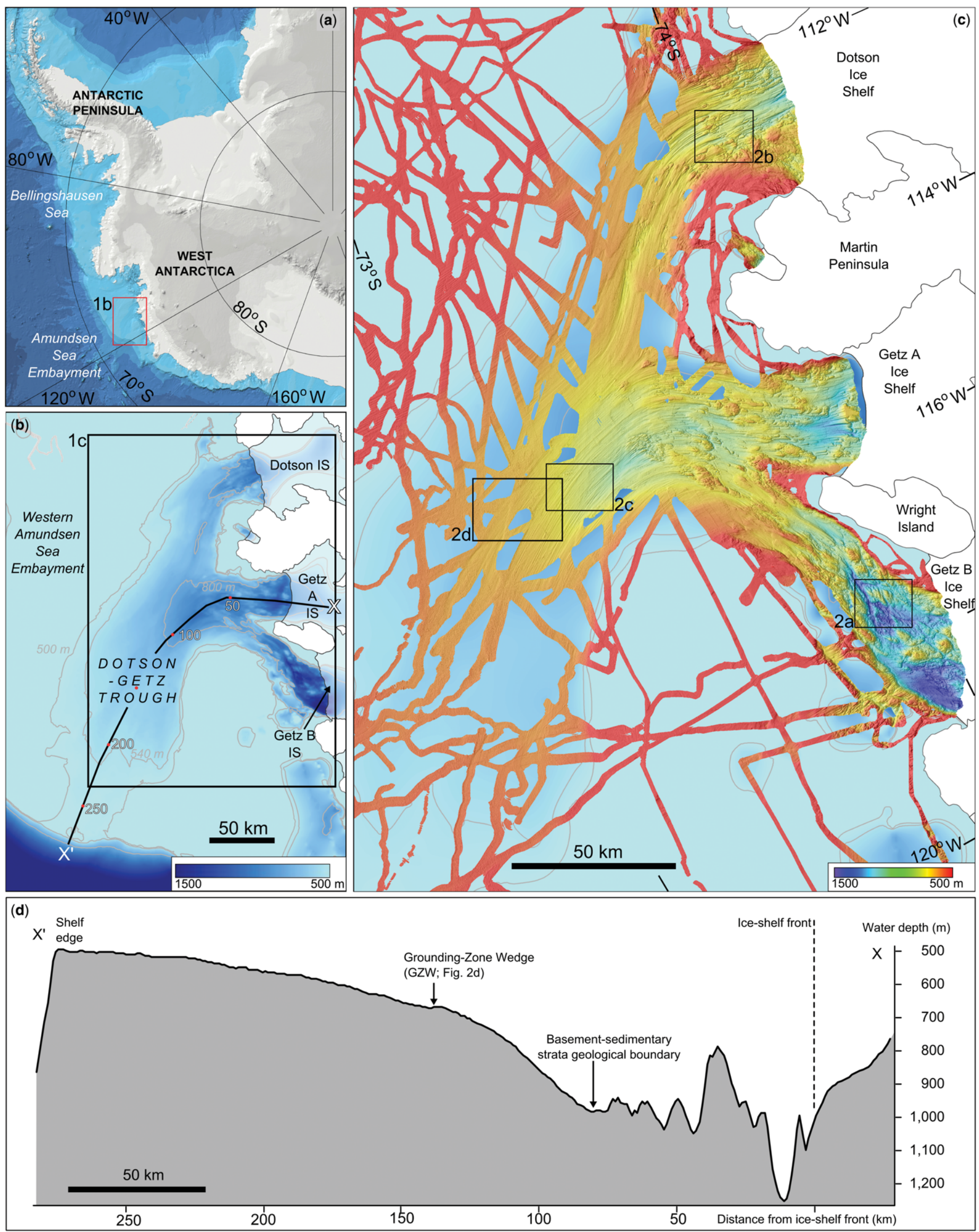

Fig. 1. Compilation of multibeam-bathymetric data from the Dotson-Getz Trough, West Antarctica. (a) Location of study area (red box; map from IBCSO v. 1.0) (b) Bathymetry of the Dotson-Getz Trough showing convergent tributaries; data from Nitsche et al. (2007). IS, ice shelf. (c) Multibeam-bathymetric data for the Dotson-Getz trough and tributary regions, collated from published datasets (UK, German, Swedish and US), illustrating the variety of seafloor landforms. (d) Profile along the trough axis showing the boundary between crystalline bedrock and seaward-dipping sedimentary strata, and a mid-trough grounding-zone wedge on the shoaling seafloor. Profile $\mathrm{x}-\mathrm{x}^{\prime}$ is located in (b). VE $\times 120$. 


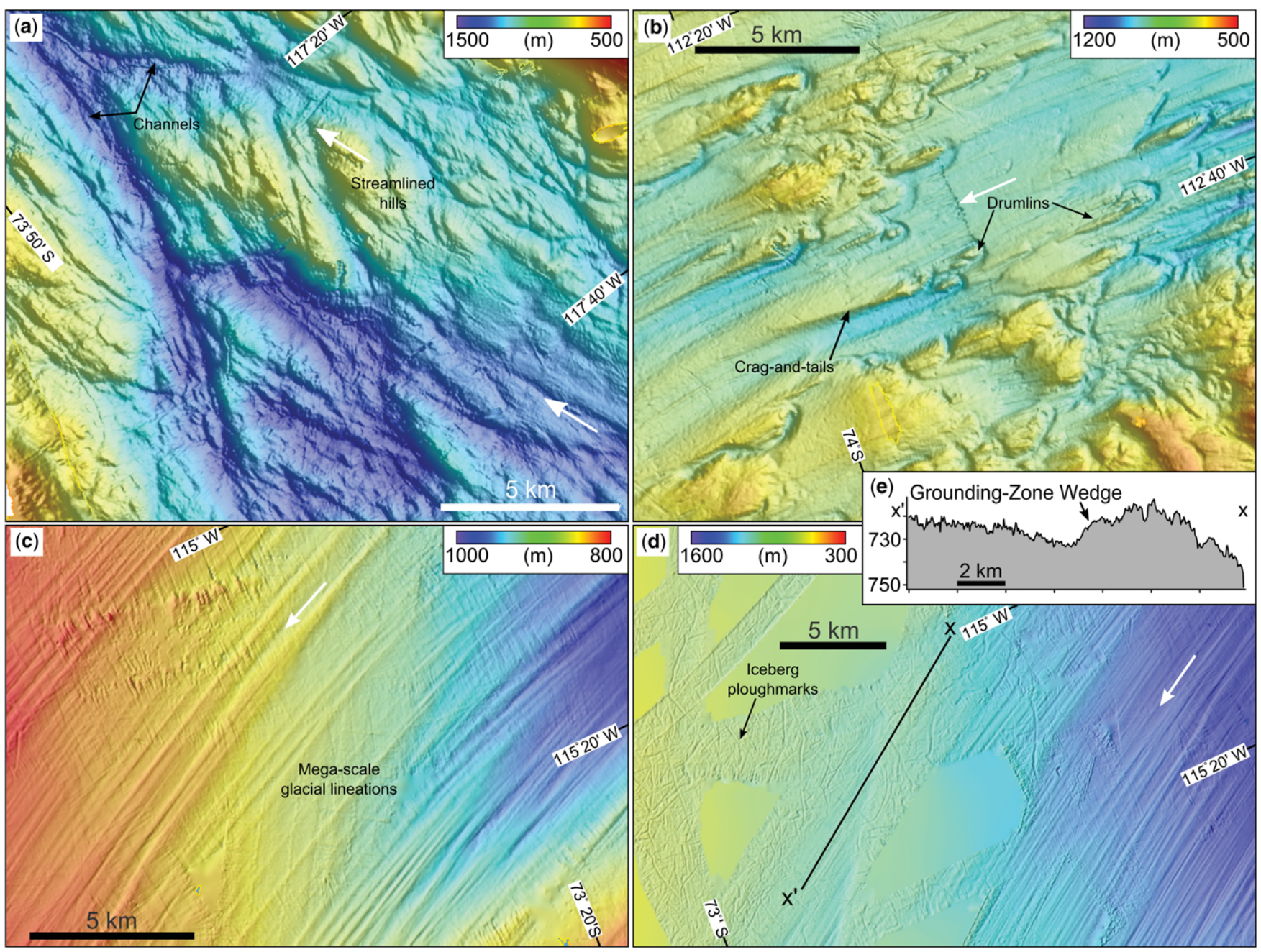

Fig. 2. (a) Multibeam-bathymetric data for inner Getz B region showing deep basins, streamlined bedrock and channels. For a, c, d, acquisition systems Atlas Hydrosweep DS-2, Kongsberg EM120 and SeaBeam 3050. Grid-cell size $35 \mathrm{~m}$. (b) Crag-and-tails, drumlinoid landforms and streamlined lineations form a complex inner-shelf terrain on crystalline bedrock in front of the Dotson ice shelf. Acquisition system Kongsberg EM120. Frequency $12 \mathrm{kHz}$. Grid-cell size $30 \mathrm{~m}$.

(c) Streamlined MSGLs in the main trough, formed in a sedimentary bed. (d) Lineations terminating seaward at a grounding-zone wedge. Iceberg ploughmarks occur in shallower regions. (e) Topographic profile $\mathrm{x}-\mathrm{x}^{\prime}$ showing geometry of the mid-shelf grounding-zone wedge; located in (d). VE $\times 100$. Direction of inferred ice-flow shown by white arrows.

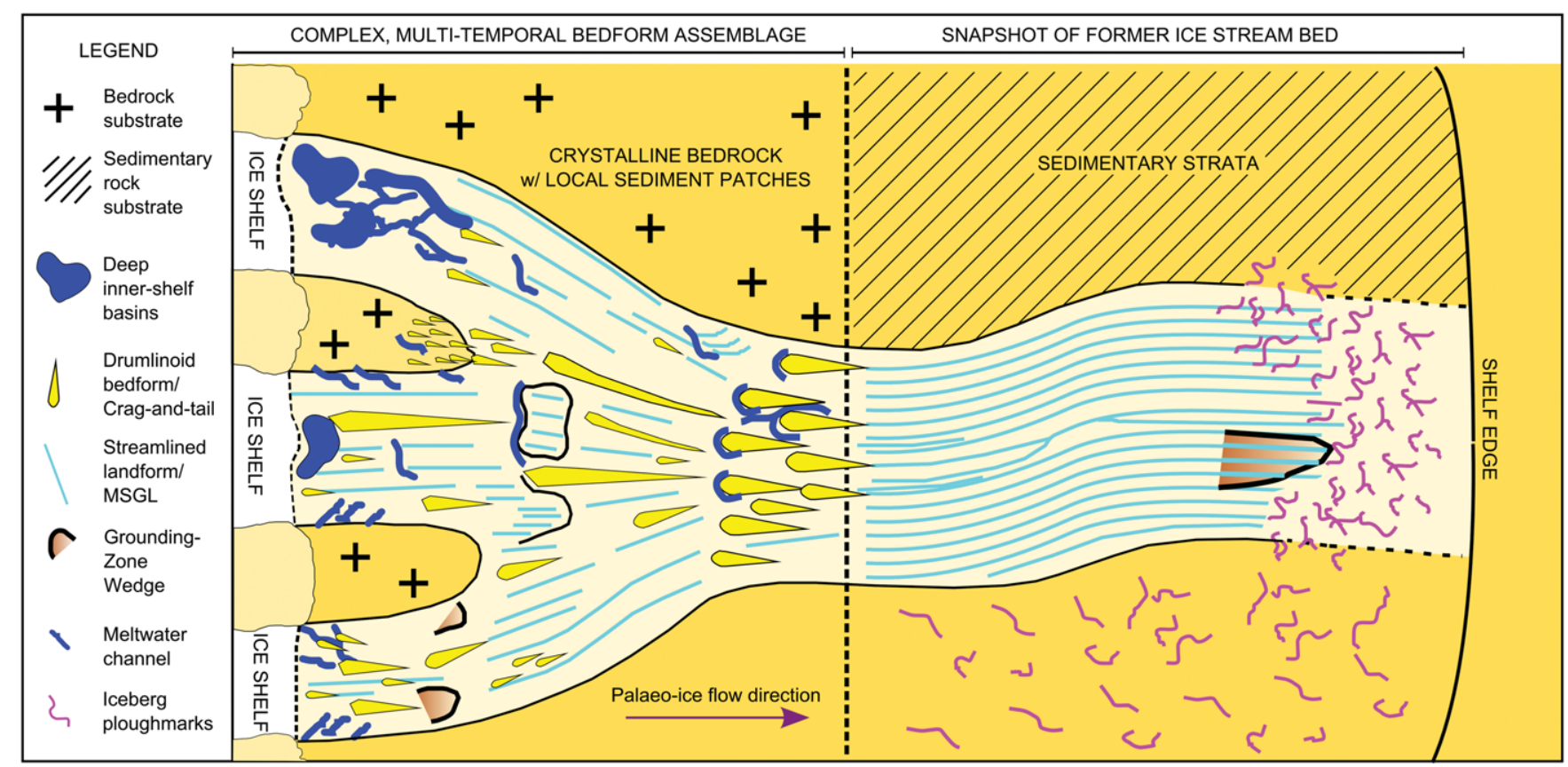

Fig. 3. Schematic model illustrating the evolution of bedforms along a West Antarctic palaeo-ice-stream bed, based on the Dotson-Getz ice-stream assemblage. 


\section{Inner shelf: basement substrate}

Deep basins on the inner parts of the Getz B continental shelf contain subglacial bedforms indicative of direct ice-sheet erosion, taking the form of short scours, whalebacks and streamlined hills. Among these erosional landforms, channels with undulating thalwegs are interpreted as evidence for erosion by the flow of past subglacial meltwater. Several of the inner-shelf basins have been locations for the storage and subsequent evacuation of subglacial meltwater, and may form part of a wider inner-shelf channel network assemblage suggestive of intensive meltwater modification. Scoured topography extending out of the basin is similar morphologically to landscapes formed along the Palmer Deep palaeoice-stream trunk (Domack et al. 2006), which have been interpreted as formed by lake outburst events beneath past ice sheets.

Drumlinoid landforms, crag-and-tails and other streamlined hills across the inner-shelf tributary troughs are all interpreted as subglacial landforms recording the interaction of ice with the underlying geology. Notably, across the inner shelf these subglacial landforms possess a range of elongations from very short and stubby to highly elongate. The varied landform assemblage in these areas probably reflects a mixture of features formed during past phases of subglacial erosion, as well as depositional landforms produced during the most recent phase of ice-sheet advance and retreat during the last glaciation. Their high spatial variability also indicates a complex ice-stream basal regime with patches of dilatant till accommodating flow by deformation, interspersed with zones of exposed bedrock with flow by basal sliding. Evidence for intervening and adjacent channel networks among the landforms also suggests the role of channelized meltwater in influencing former ice flow.

The swarm of drumlins immediately landward of the transition between basement and sediment substrates is interpreted as a set of till-formed landforms, but interweaving channels may also relate to a zone of the ice-sheet bed in which meltwater was an important erosional geomorphic agent (Nitsche et al. 2013).

\section{Middle to outer shelf: sedimentary substrate}

The highly elongate ridge-groove landforms beyond the substrate transition (Fig. 1d) reflect a much simpler assemblage of features, and are mega-scale glacial lineations (MSGLs) formed at an icestream base. Acoustic profiles through the shallow stratigraphy show that the MSGLs are formed in the top of a 5-10 m thick acoustically transparent layer, which has been identified in sediment cores as a weak, muddy, deformation till.

The seafloor wedge which interrupts the downflow continuity of these MSGLs is interpreted as a grounding-zone wedge (GZW), formed by the advection and deposition of subglacial till at the margin of the Dotson-Getz palaeo-ice stream during a past grounding-line stillstand (Batchelor \& Dowdeswell 2015). It is unclear whether the GZW relates to the termination of a past glacial phase (e.g. the limit of the Last Glacial Maximum ice sheet), or to a landform constructed during episodic retreat up the trough axis during deglaciation. However, the presence of MSGLs beyond the wedge crest suggests the latter is more likely. The most northerly reach of these subglacial lineations cannot be traced due to subsequent removal and overprinting by curvilinear scours which are interpreted as iceberg-keel ploughmarks. These ploughmarks cover the majority of the outer shelf and cut into the seafloor to the shelf break, meaning the assemblage of subglacial signatures is limited to the middle- and inner-shelf areas for this particular palaeo-ice-stream system.

\section{Discussion}

The seafloor data presented from a zone of former ice-stream convergence remain among the largest for a single ice-stream bed in Antarctica (Fig. 1c; Larter et al. 2009). They demonstrate a complex assemblage of subglacial landforms, in which the downflow progression of features is not as simple as prior models have proposed (Fig. 3; Wellner et al. 2001). Instead, a detailed analysis of the landform suite shows that bed geology is a likely major control on the overall landform imprint. Furthermore, our analysis reveals that the bed signature has been modified more than once by ice-stream flow, thus forming a multi-temporal assemblage. MSGLs on sedimentary substrate record a fresh landform-set probably developed during the last termination, whereas the more complex and varied, well-preserved inner-shelf landform set on a bedrock substrate shows multiple phases of past erosion and deposition beneath streaming flow (Graham et al. 2009).

Significantly, the presence of elongate landforms in front of the present ice shelves in the Dotson and Getz region indicates that ice streams flowed over this topography during a previous glacial stage. The convergent pattern of bedforms also necessarily implies flow acceleration in the former system. Previous studies had interpreted the onset of ice-streaming at the transition from basement to sedimentary strata on the shelf, but observations here leave little doubt that streaming flow existed much further south, and was perhaps initiated further back in the ice-sheet interior today.

Changes in the along-flow bed substrate have clearly controlled the preservation and overall geomorphological signature left behind in the submarine landscape today, but have not been a direct control on the onset of ice-stream flow itself. Nevertheless, measured elongations of landforms do demonstrate a consistent downstream increase, which suggests that ice velocity has probably modulated the landform pattern as a whole. Elongation metrics and landform types may, therefore, remain as a reasonable proxy for relative former ice-flow speeds along the palaeo-ice-stream pathway despite the strong substrate control.

\section{References}

Bamber, J.L., Vaughan, D.G. \& Joughin, I. 2000. Widespread complex flow in the interior of the Antarctic Ice Sheet. Science, 287, 1248-1250.

BAtchelor, C.L. \& Dowdeswell, J.A. 2015. Ice-sheet grounding-zone wedges (GZWs) on high-latitude continental margins. Marine Geology, 363, 65-92.

Domack, E.W., Amblas, D. ET AL. 2006. Subglacial morphology and glacial evolution of the Palmer Deep outlet system, Antarctic Peninsula. Geomorphology, 75, 125-142.

Gohl, K., Uenzelmann-Neben, G. ET AL. 2013. Seismic stratigraphic record of the Amundsen Sea Embayment shelf from pre-glacial to recent times: evidence for a dynamic West Antarctic ice sheet. Marine Geology, 344, 115-131.

Graham, A.G.C., LARTER, R.D. ET AL. 2009. Bedform signature of a West Antarctic palaeo-ice stream reveals a multi-temporal record of flow and substrate control. Quaternary Science Reviews, 28, 2774-2793.

LARTER, R.D., GraHAM, A.G.C. ET AL. 2009. Reconstruction of changes in the Amundsen Sea and Bellingshausen Sea sector of the West Antarctic Ice Sheet since the Last Glacial Maximum. Geology, 100, 55-86.

Lowe, A.L. \& Anderson, J.B. 2002. Reconstruction of the West Antarctic Ice Sheet in Pine Island Bay during the Last Glacial Maximum and its subsequent retreat history. Quaternary Science Reviews, 21, $1879-1897$

Lowe, A.L. \& ANDERSon, J.B. 2003. Evidence for abundant subglacial meltwater beneath the paleo-ice sheet in Pine Island Bay, Antarctica. Journal of Glaciology, 49, 125-138.

Nitsche, F.O., LARTER, R.D. ET AL. 2007. Bathymetry of the Amundsen Sea continental shelf: implications for geology, oceanography, and glaciology. Geochemistry, Geophysics, Geosystems, 8, http://doi. org/10.1029/2007GC001694

Nitsche, F.O., GoHL, K. ET AL. 2013. Paleo ice flow and subglacial meltwater dynamics in Pine Island Bay, West Antarctica. Cryosphere, 7, 249-262.

Wellner, J.S., Lowe, A.L., Shipp, S.S. \& Anderson, J.B. 2001. Distribution of glacial geomorphic features on the Antarctic continental shelf and correlation with substrate: implications for ice behaviour. Journal of Glaciology, 47, 397-411. 